\title{
Visualising Iron Gall Ink Underdrawings In 16th Century Paintings In-Situ By Micro-XRF Scanning (MA-XRF) And LED-Excited IRR (LEDE-IRR)
}

Mareike Gerken ( $\sim$ gerken@stadelmuseum.de )

Städel Museum Frankfurt https://orcid.org/0000-0003-1002-6979

Jochen Sander

Städel Museum Frankfurt

Christoph Krekel

Staatliche Akademie der Bildenden Künste

\section{Research Article}

Keywords: iron gall ink, underdrawing, panel paintings, MA-XRF, IRR, wavelength, microscopy, Holbein the Elder, Cima da Conegliano, 16th century,

Posted Date: January 7th, 2022

DOI: https://doi.org/10.21203/rs.3.rs-1228966/v1

License: (c) (i) This work is licensed under a Creative Commons Attribution 4.0 International License. Read Full License 


\title{
Visualising iron gall ink underdrawings in $16^{\text {th }}$ century paintings in-situ by micro-
}

\section{XRF scanning (MA-XRF) and LED-excited IRR (LEDE-IRR)}

\author{
Mareike Gerken ${ }^{1,2, *}$, Jochen Sander ${ }^{1,3}$ and Christoph Krekel ${ }^{2}$ \\ Städel Museum, Frankfurt am Main; Schaumainkai 63, 60596 Frankfurt am Main. \\ Staatliche Akademie der Bildenden Künste, Stuttgart; Am Weißenhof 1, 70191 Stuttgart. \\ Goethe Universität Frankfurt am Main, Senckenberganlage 31, 60325 Frankfurt am Main. \\ Correspondence: gerken@staedelmuseum.de; Tel.: +49(0)69-605098-126
}

Abstract: Until today, iron gall ink is classified as an exceptional underdrawing material for paintings. A certain identification is always based on invasive analysis. This article presents a new non-destructive analysis approach using micro-X-ray fluorescence scanning (MA-XRF), LED-excited IRR (LEDE-IRR) using a narrow wavelength-range of infrared radiation (IR) and stereomicroscopy for visualising and identifying iron gall ink underdrawings. To assess possibilities and limits of this non-invasive approach, results were compared to invasive examinations on cross-sections using scanning electron microscopy with energy dispersive X-ray spectroscopy (SEM/EDX). The approach is tested on panel paintings of Hans Holbein the Elder and Giovanni Battista Cima da Conegliano. The holistic setup could successfully visualise underdrawing lines made with iron gall inks, which formerly remained invisible by means of conventional IRR. For the first time, a direct access to a formerly invisible type of underdrawing is created, allowing to harness the whole iron gall ink underdrawing for interdisciplinary studies.

Keywords: iron gall ink; underdrawing; panel paintings; MA-XRF; IRR; wavelength; microscopy; Holbein the Elder; Cima da Conegliano; $16^{\text {th }}$ century;

\section{Introduction}

Iron gall ink has been used as a drawing and writing material from roughly around the $3^{\text {rd }}$ century $B C$ and was widely spread since Medieval times [1] (p. 30) [2] (p. 25-26). ${ }^{1}$ The ink is a complex reaction product of ferrous sulphate from vitriol and soluble gallotannins from insect galls, which was utilised in an aqueous solution with a gum binding agent [2] (p. 26). Despite being the most important ink in European history, it has rarely been identified as an underdrawing material for paintings. Since underdrawings of paintings are usually covered by several heterogenous painting layers, they are commonly studied by infrared (IR) radiation-based methods such as infrared reflectography (IRR). Because IRR is particularly sensitive for carbon-based underdrawing materials, iron gall ink underdrawings only rarely become visible by IR [1] (p. 31). Until now, reliable identification of iron gall ink in underdrawings has always been based on invasive analysis, e. g. [3] (p. 75), [4] (p. 134) or [5] (p. 20). However, the diversity of origin and dating of the few paintings with verified iron gall ink underdrawings hint at a more widespread use than is currently assumed. A new non-destructive analysis approach, which is not only able to chemically identify but also visualise the distribution of iron gall ink underdrawings, has now been developed and is currently being tested in a research project at the Städel

\footnotetext{
${ }^{1}$ First evidence on the use of iron gall ink could be found by PIXE analysis on Egytian papyri originating from the $3^{\text {rd }}$ to $1^{\text {st }}$ century $B C$, whereas the first recipe from the European area is dated into the $7^{\text {th }}$ century AD [2] (p. 25-26).
} 
Museum Frankfurt in cooperation with the Stuttgart State Academy of Art and Design and the Städel Cooperation Professorship at the Institute of the Art History at the Goethe University Frankfurt. It combines micro-X-ray fluorescence scanning (MA-XRF) with an advanced use of IRR, that uses IR-LEDs with a narrow wavelength range as excitation radiation, focussing on the impact of measurement parameters, value of trace elements and in-depth postprocessing routines. To evaluate possibilities and limits, the approach was accompanied by scanning electron microscopy with energy dispersive $\mathrm{X}$-ray analysis (SEM/EDX) on cross-sections.

The main inorganic component of iron gall ink is vitriol, an iron sulphate $\left(\mathrm{FeSO}_{4}\right)$ with varying impurities of $\mathrm{CuSO}_{4}$, $\mathrm{MnSO}_{4}$ and $\mathrm{ZnSO}_{4}$. The proportion of these components varies depending on the mining site and extraction method of the vitriol used [2], [6] and [7]. For instance, while vitriolum goslarensis, originating from Goslar (Germany), has a very high amount of $\mathrm{ZnSO}_{4}(11 \%)$, vitriolum romanum does not contain $\mathrm{Zn} \mathrm{[6]} \mathrm{(p.} \mathrm{130).}{ }^{2} \mathrm{XRF}$ based analytical techniques such as MA-XRF are highly sensitive for the identification of mid-range chemical elements such as $\mathrm{Fe}, \mathrm{Cu}, \mathrm{Mn}$ and $\mathrm{Zn}$ [8] (p. 763). MA-XRF scanning has proven to be a rewarding non-invasive and in-situ analysis technique for historical paintings, e. g. [8-12]., after its first successful application in 2008 [9] and the introduction of the first commercially available mobile X-ray tube-based MA-XRF instrument [10]. Main principles of XRF can be found elsewhere [13]. In general, the distribution of mid-range elements can be visualised by acquiring several thousands to millions single XRF spectra in a two-dimensional scan. From this, chemical information on surface and sub-surface layers can be derived, allowing to infer on pigments and the technological build-up of paintings. Although suitable, MA-XRF has not been consciously used to analyse and visualise iron gall ink underdrawings in paintings until today. First attempts to study non-carbon-based underdrawings that are invisible in conventional IRR were performed with Point- $\mu$-XRF (P- $\mu$-XRF), e.g. [14]. The main disadvantage of P-XRF is, that elemental signals cannot be unambiguously assigned to specific subsurface layers in the heterogenous multi-layered structure of paintings. Further, $\mathrm{Fe}$ is not only the main inorganic component of iron gall inks but also of ochre pigments, which were not only also used for underdrawing paintings but also often appear as pigments in paint layers. Therefore, trace elements present in iron gall ink such as $\mathrm{Cu}$ and $\mathrm{Zn}$ become highly important to distinguish between both materials. P-XRF analysis on inorganic components of iron gall ink on parchment and paper, has been studied by Krekel [2] and Hahn [15], the latter resulting in a fingerprint model based on XRF data quantification [16-17], that uses ratios of impurity metals in vitriol such as $\mathrm{Cu}, \mathrm{Mn}$ and $\mathrm{Zn}$ related to Fe as main component to distinguish between different inks [16-17]. Unfortunately, this fingerprint model is hardly applicable on underdrawings, as these are usually completely covered by paint layers. Nevertheless, the joint presence of side elements such as $\mathrm{Cu}$ and $\mathrm{Zn}$ could distinguish between different Fe-containing underdrawing materials such as ochres and iron gall inks. The visualisation of lost scriptures written with iron gall ink in palimpsests [18-19] or of iron gall ink underdrawings underneath manuscript illuminations [20] by MA-XRF hint at the potential success for visualising the distribution of iron gall ink underdrawings in paintings. This is also supported by published MA-XRF results of Leonardo da Vinci's "Madonna of the Rocks" from the National Gallery London, which revealed the distribution of a Zn-containing underdrawing material, that has not yet been further specified [21].

Material identification of an underdrawing media could be achieved by combining different analytical techniques which are able to gain information on different characteristics of a material. Using IRR with different narrow

\footnotetext{
${ }^{2}$ Hickel localises the mining site of vitriolum romanum on the Isle of Elba, although it could likely be a trade name for a product with varying origins.
} 
wavelength ranges (LEDE-IRR), different IR reflectance properties of historical underdrawing materials can be studied. According to recent reflectance measurements, iron gall inks absorb IR radiation up to $1200 \mathrm{~nm}$ [22] (p. 58), while ochre already become transparent at $850 \mathrm{~nm}$ [23] (p. 16). An iron gall ink underdrawing could be thus determined, if the underdrawing lines absorb radiation up to $1200 \mathrm{~nm}$ and become invisible in higher wavelengths. A similar approach was first tested in the 1990s with filter sets, that transmit only certain wavelengths, but was not pursued because resulting images were very dark [24-25]. A novel and more promising concept was recently developed by Geffken, Krekel and Dittmar at the Institute for Conservation Sciences of the State Academy of Art and Design Stuttgart in cooperation with the Steinbeis Transfer Centre of Aalen University [22]. IR-LED panels with narrow wavelength ranges as excitation radiation (LEDE-IRR), that can either be used individually or in combination, proved to enable a better detection of underdrawing media such as iron gall ink [22] (p. 124).

\section{Materials and Methods}

\subsection{Panel Paintings}

Three panel paintings from the collection of the Städel Museum were chosen for the study, as they only partly showed underdrawing lines during preliminary conventional IRR with halogen lights, which emit a broad spectrum of wavelengths (Table 1).

Table 1. Overview and general information of the examined panel paintings.

\begin{tabular}{llll}
\hline Artist & Title & Date & Inv. № \\
\hline Hans Holbein the Elder & Tree of Jesse ${ }^{1}$ & 1501 & HM 6 \\
Hans Holbein the Elder & Bearing of the Cross ${ }^{1}$ & 1501 & HM 15 \\
G. B. Cima da Conegliano & Virgin and Child & ca. 1500-1504 & 852 \\
\hline
\end{tabular}

${ }^{1}$ Part of the Frankfurt Dominican Altarpiece.

Iron gall ink underdrawings, partly mixed with carbon-based black pigments, were determined by Dietz in 2015 in the panel paintings "Tree of Jesse" (Inv. № HM 6) and "Bearing of the Cross" (Inv. № HM 15) of the Frankfurt Dominican Altarpiece by Hans Holbein the Elder by means of SEM/EDX analysis on cross-sections [4] (p. 505-514). The panel painting "Virgin and Child" by Giovanni Battista Cima da Conegliano (Inv. № 852) was selected because underdrawings with iron gall ink had been previously discovered in paintings by the Italian artist at the National Gallery London [1] (p. 31) and National Gallery of Scotland, Edinburgh [26] (p. 8).

\subsection{Analysis}

The underdrawing of all three paintings was analysed by MA-XRF and LEDE-IRR. Data evaluation was accompanied by stereomicroscopy. Results were compared to invasive methods using SEM/EDX on cross-sections.

MA-XRF was performed using a Bruker M6 Jetstream [9], operated with a Rh-target X-ray tube at $50 \mathrm{kV}$ and $600 \mu \mathrm{A}$, equipped with a $30 \mathrm{~mm}^{2}$ SDD spectrometer detecting $275 \mathrm{kcps}$ and a range up to $40 \mathrm{keV}$. A beam size of $100 \mu \mathrm{m}$ was used for all scans. Different acquisition parameters were employed due to the different requirements of the scans (Table 2). Overall scans were performed to get a first impression of the elements present and their distribution, whereas detail scans were used to study the features of the underdrawing lines. In addition, a detail of the head of Jesse in Holbein the Elder's "Tree of Jesse" (Inv. № HM 6) was selected to test the influence of the dwell time per pixel 82 83 
on the visibility of the underdrawing lines, starting with the fastest scan time possible up to a dwell time that allowed to show the underdrawing in detail.

Table 2. Varying measurement parameters of MA-XRF analysis chosen for different scans.

\begin{tabular}{lllll}
\hline Inv. No & Scan & Localisation & Step size & Dwell time \\
\hline HM 6 & Overall 1-2 & Lower part of the panel & $375 \mu \mathrm{m}$ & $25 \mathrm{~ms} / \mathrm{Px}$ \\
& Detail 1 & Head of Jesse & $305 \mu \mathrm{m}$ & $3.04^{1} \mathrm{~ms} / \mathrm{Px}$ \\
& Detail 1 & Head of Jesse & $305 \mu \mathrm{m}$ & $10 \mathrm{~ms} / \mathrm{Px}$ \\
& Detail 1 & Head of Jesse & $305 \mu \mathrm{m}$ & $50 \mathrm{~ms} / \mathrm{Px}$ \\
& Detail 1 & Head of Jesse & $305 \mu \mathrm{m}$ & $100 \mathrm{~ms} / \mathrm{Px}$ \\
& Detail 2 & King David & $305 \mu \mathrm{m}$ & $250 \mathrm{~ms} / \mathrm{Px}$ \\
\hline HM 15 & Overall 1 & Lower left part of the panel & $375 \mu \mathrm{m}$ & $25 \mathrm{~ms} / \mathrm{Px}$ \\
\hline 852 & Overall 1 & Overall & $375 \mu \mathrm{m}$ & $25 \mathrm{~ms} / \mathrm{Px}$ \\
& Detail 1 & Dress of the Virgin & $305 \mu \mathrm{m}$ & $100 \mathrm{~ms} / \mathrm{Px}$ \\
\hline
\end{tabular}

${ }^{1}$ Fastest scan time possible.

MA-XRF datasets were processed and evaluated using Bruker M6 software, datamuncher [27] and PyMca [28-29]. IRR of the paintings by Holbein the Elder (Inv. № HM 6, Inv. №HM 15) were performed with an Osiris-A1 camera, IRR of "Virgin and Child" by Cima da Conegliano (Inv. № 852) with a Vidicon. Conventional IRR with a broad range of wavelengths using halogen-based Hedler ${ }^{\circledR}$ HT 19 s lights as excitation source were already existent. ${ }^{3}$ IRR with five different wavelengths ( $880 \mathrm{~nm}, 940 \mathrm{~nm}, 1060 \mathrm{~nm}, 1330 \mathrm{~nm}$ and $1550 \mathrm{~nm}$ ) was performed with IR-LED test panels as excitation source in a dark room. These test panels were built at the Steinbeis Transfer Centre at Aalen University and illuminate an area of $20,0 \times 40,0 \mathrm{~cm}$, hence only details of the panels could be studied [30]. For optical microscopy a Leica MZ 6 equipped with two Schott KL 1600 LED lights was used. Cross-section analysis of the paintings by Holbein the Elder (Inv. № HM 6, Inv. №HM 15) were performed in 2015 by Dietz [4], whereas cross-sections of "Virgin and Child" by Cima da Conegliano (Inv. № 852) were produced during this project. All microsamples were embedded in Technovit 2000 LC and grinded with Micro Mesh (granulation 1500-12000). Analysis of all cross-sections was performed with Leica DM RM with a magnification of 500 for visible (VIS) in dark field illumination and ultraviolet (UV) fluorescence (filter set D, bandpass 355-425) for microscopy and a Zeiss VP-REM EVO 60 with a Si-detector (SDD) by Bruker for SEM/EDX. EDX parameters were chosen according to Dietz [4] (p. 101).

\section{Results}

In the following, first results on the application of the novel analysis routine on iron gall ink underdrawings are presented. The first case study on paintings by Holbein the Elder focusses on possibilities and limits of visualising iron gall ink underdrawings. The second case presents a detailed study of the newly discovered iron gall ink underdrawing in a panel painting by Cima da Conegliano.

\footnotetext{
3 The wavelength range of these lights could not be determined until now. Comparable Hedler H25s halogen lamps excite a wavelength range from $\lambda=150-7500 \mathrm{~nm}$ with $\lambda_{\text {peak }}$ at $1250 \mathrm{~nm}$ [22] (p. 104).
} 
Hans Holbein the Elder (c. 1465-c. 1524) was a German painter active between Late Medieval and early Renaissance. Around 1500 he and his workshop, where he worked together with his workshop members including his brother Sigmund Holbein, created a couple of large and important altarpieces. Among these is the High Altarpiece of the Dominican Church in Frankfurt, painted in 1501 [31], whose art-technology was examined by Dietz in 2015 [4]. Today, eleven panels with an average size of $166,0 \times 150,0 \mathrm{~cm}$ and the predella of the Frankfurt Dominican Altarpiece $(76,3 \times$ $277,5 \mathrm{~cm}$ ) belong to the collection of the Städel Museum Frankfurt (Supplement 1). Nine of these panel paintings were underdrawn with iron gall ink [4] (p. 505-514), which Dietz identified by studying optical features, conventional IRR and SEM/EDX analysis on cross-sections [4] (p. 138). The ink contained Zn, Cu and Fe (ratio 1:1,3:5,7). The other three panel paintings were either not sampled or samples did not include an underdrawing layer. In all nine cases in which the materiality of the underdrawing could be studied both iron gall ink as well as carbon-based black pigments could be detected. In six of the panel paintings iron gall ink and carbon black pigments were not only used separately, but also in mixture with each other [4] (p. 505-514). Hence it is not surprising, that the underdrawing could not be fully visualised by means of IRR with halogen lamps (Supplement 2 a, 3 a). Still, some of the lines invisible in IRR show through overlying lead white painting layers, which became transparent due to the formation of lead soaps [4] ( $p$. 135).

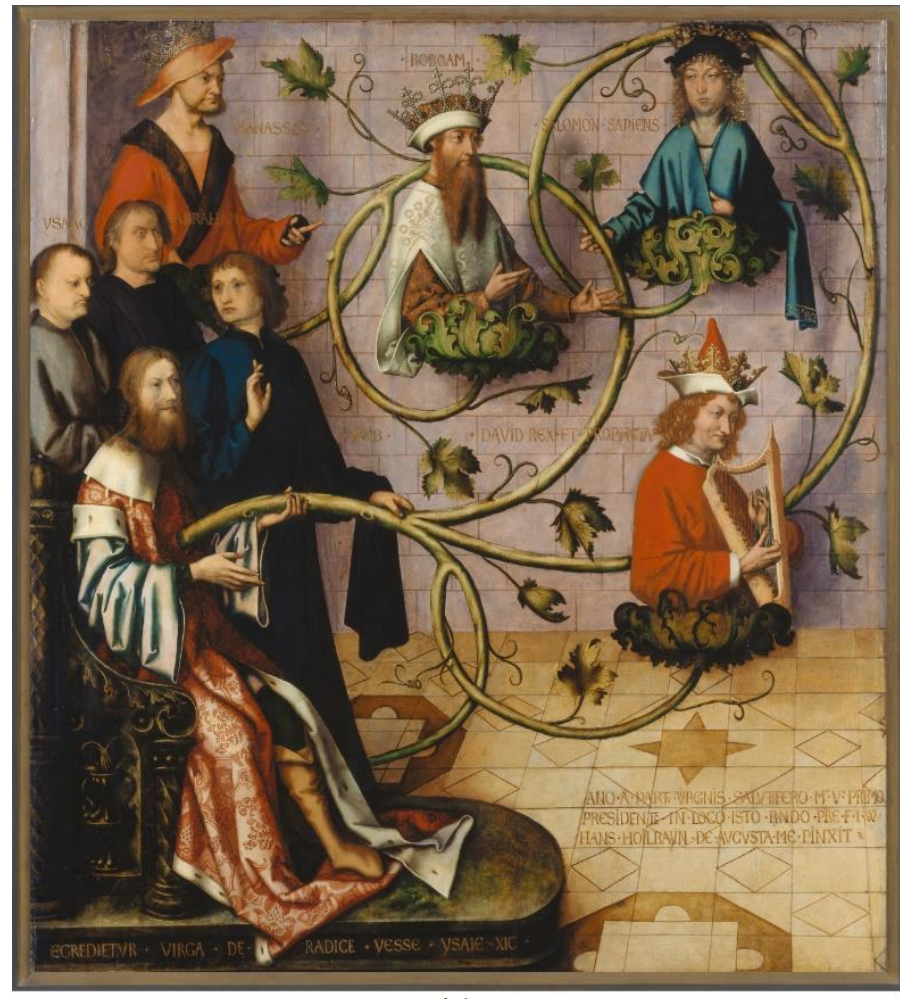

(a)

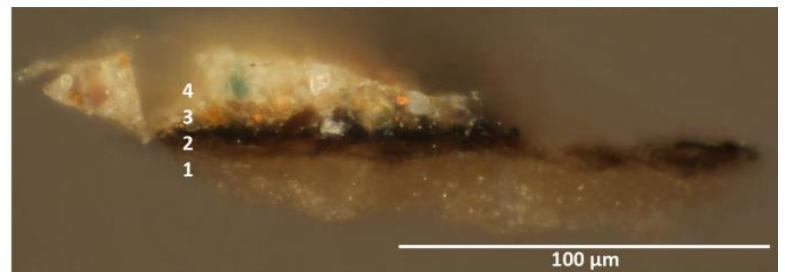

(b)

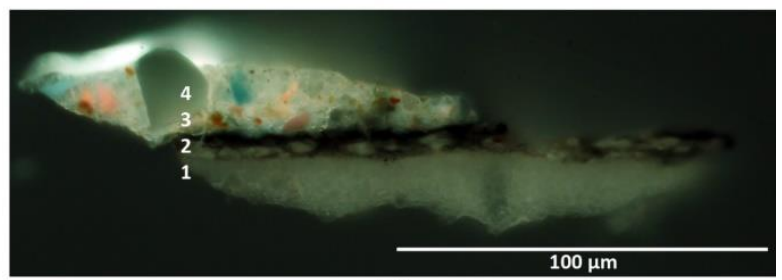

(c)

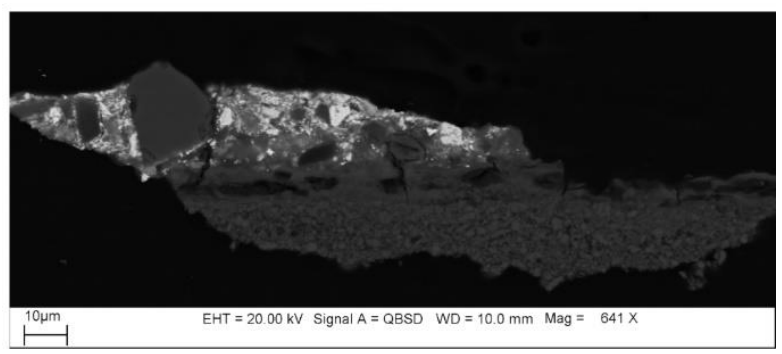

(d)

Figure $1 \mathrm{H}$. Holbein the Elder, "Tree of Jesse" (Inv. № HM 6), exterior wings, High Altarpiece of the Dominican Church. (a) Overall VIS image; (b) Cross-section (S70) in dark field, taken from the incarnate of Jesses' face containing an iron gall ink underdrawing (layer 2); (c) Cross-section (S70) in UV; (c) Backscattered electron image (BSE) of cross-section (S70) in SEM/EDX.

MA-XRF and LEDE-IRR were applied on two panels of the altarpiece in overall and detail scans. The lower part of the "Tree of Jesse" (Inv. № HM 6) is localised at the lower half on the exterior of the left outer wing of the retable (Figure 1 a) and was (at least partly) underdrawn with pure iron gall ink (Figure 1 b-c) [4] (p. 513). In contrast, the panel 
"Bearing of the Cross" (Inv. № HM 15) is part of the inner wings depicting the Passion of Christ, locatable on the lower exterior. In areas accessible to MA-XRF scanning, iron gall ink was used in mixture with a carbon black pigment for compositional drawings [4] (p. 506). ${ }^{4}$ Due to the limited accessibility of the large and heavy panel paintings, which are permanently on display, only lower parts of both panels could be examined (Supplement 2 b, 3 b). MA-XRF detail scans were performed on Jesses' head and King David’s harp, both located in lower parts of "Tree of Jesse" (Inv. № HM 6) (Supplement 2 b).

\subsubsection{Analysis}

While Fe-K and Cu-K elemental maps of the MA-XRF overview scans are dominated by strong signals stemming from Fe- and Cu-rich pigments, which are present in the painting layers (Figure $2 \mathrm{a}-\mathrm{b}$ ), the distribution of Mn-K is too noisy to show details, especially of sub-surface layers (Figure $2 \mathrm{c}$ ). Nonetheless, the iron gall ink underdrawing is visible within the Zn-K distribution maps of both panel paintings (Figure $2 \mathrm{~d}$ ), no matter if the ink was used pure (Inv. № HM 6) or in mixture with a carbon black pigment (Inv. № HM 15) (Supplement 3 c-f). Although Zn is also present in some of the copper green and blue pigments of the paint, the course of the underdrawing lines as well as the ink's fluid application are revealed by Zn-K elemental map, e.g. garment and head of Jesse or King David's harp.

\footnotetext{
${ }^{4}$ For a better presentation, visual results on the latter (Inv. № HM 15) can be found in the Supplementary Material because they are highly comparable to results gained for Inv. № HM 6.
} 


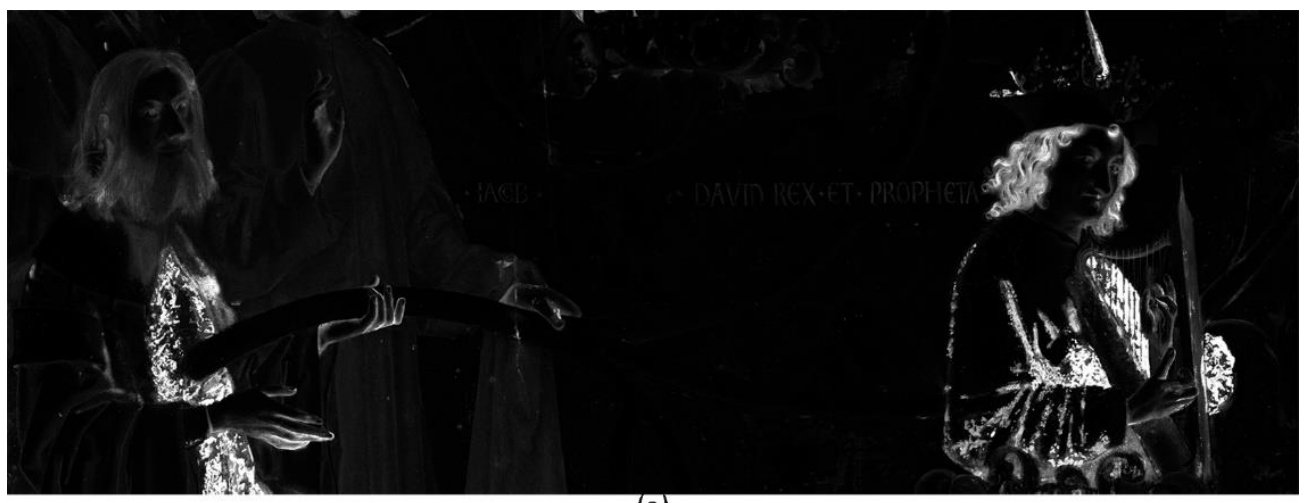

(a)

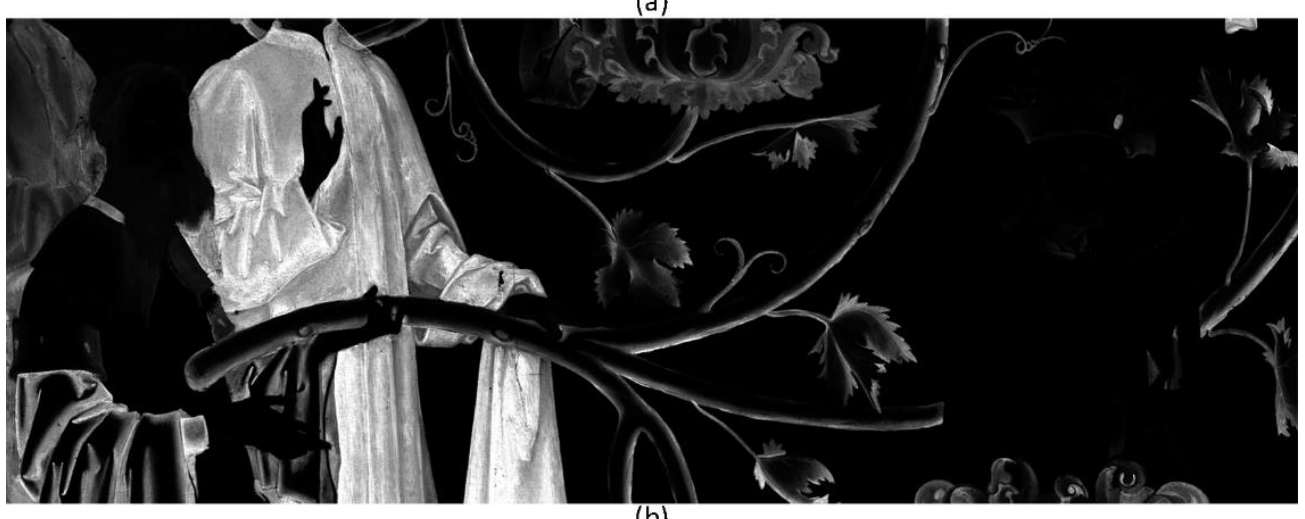

(b)

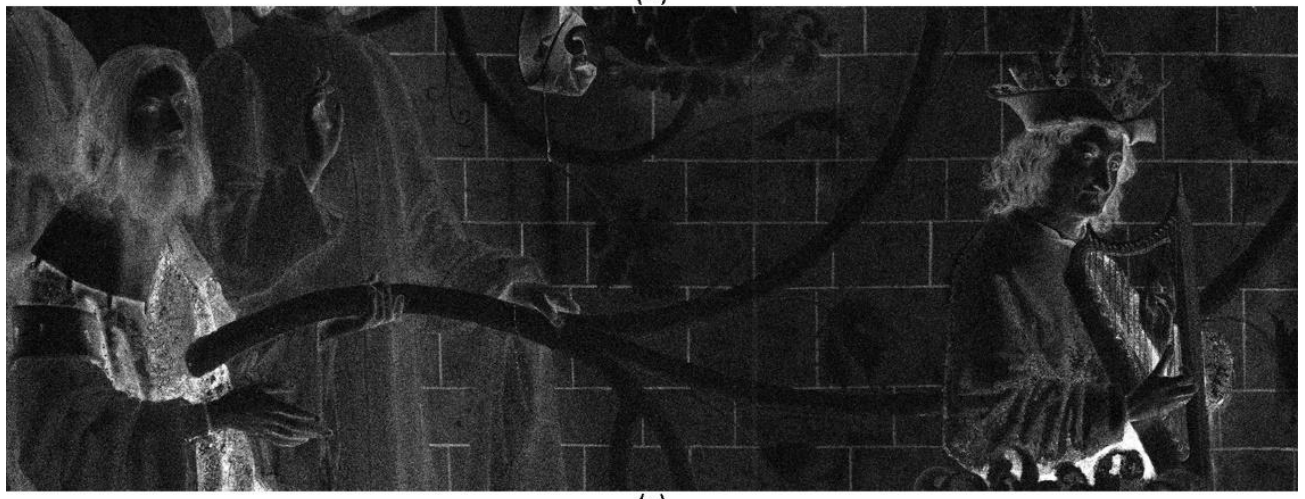

(c)

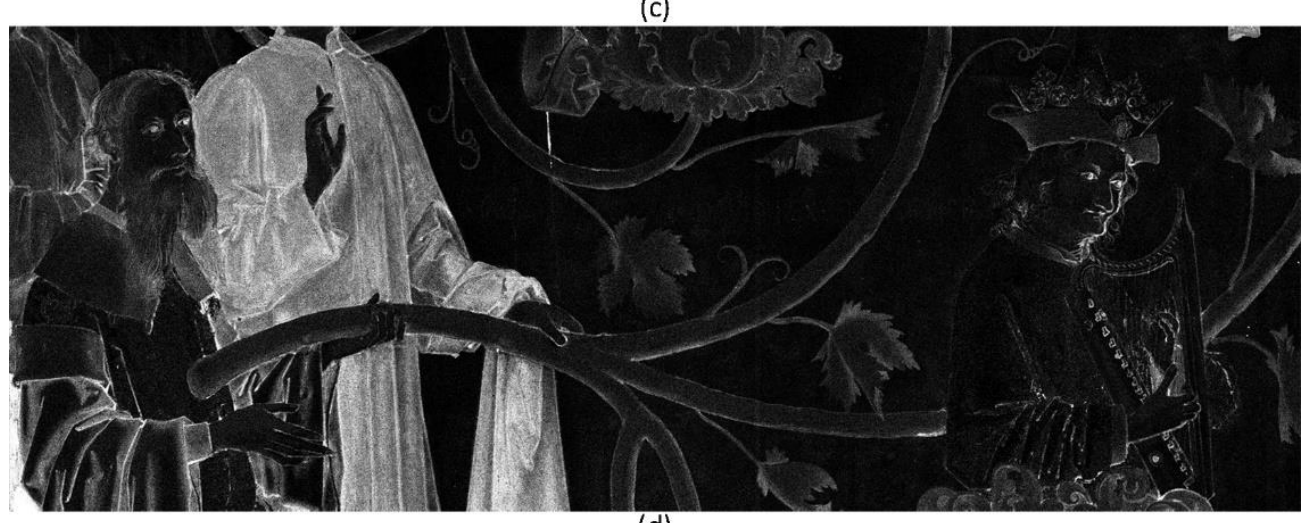

(d)

Figure $2 \mathrm{H}$. Holbein the Elder, "Tree of Jesse" (Inv. № HM 6), MA-XRF overview scans of the lower part of the panel painting. (a) Fe-K elemental map; (b) Cu-K elemental map; (c) Mn-K elemental map; (d) Zn-K elemental map.

The two detail scans of "Tree of Jesse" (Inv. № HM 6) revealed properties and application traces of the iron gall ink underdrawing in greater detail and contrast (Figure 3,4). The compositional lines visible in Zn-K maps not only roughly capture drapery of clothing and hair, but also indicate facial features in a more elaborate way with hatchings creating 
shadows and thin lines outlining wrinkles, a typical stylistic element of Holbein's underdrawings [4] (p. 146-149). Besides thickly or thinly applied Zn-rich compositional lines, lines with low elemental signals could be identified, which could either hint at a high dilution of the ink or a mixture with another material.

The visibility of the ink and its dependence on chosen MA-XRF parameters were tested in a detail scan of Jesse's head, focusing on the dwell time per pixel. While overall scans were performed with a pixel size of $375 \mu \mathrm{m}$, details were scanned with a fixed pixel size of $305 \mu \mathrm{m}$ to ensure the visibility of the underdrawing lines. In general, the step size should be chosen in accordance to the width of the underdrawing lines as well as the focus of research. In this case, a step size of $375 \mu \mathrm{m}$ proved to be a good choice for visualising the overall distribution of the ink and was still sufficient to map large areas in a reasonable time ( $24 \mathrm{~h}$ for $60,0 \times 80,0 \mathrm{~cm}$ ), whereas $305 \mu \mathrm{m}$ proved sufficient for detail scans, which enabled characteristics of the ink application to be studied in detail. The dwell time was varied in four steps appropriate to a reasonable time exposure (Table 2). The tested variation of the chosen dwell time had a great impact on the visibility of the underdrawing. At fastest stage speed - in this case $3.04 \mathrm{~ms} / \mathrm{Px}$ - the presence of $\mathrm{Zn}$ could be determined, but signals could not be clearly linked to a specific distribution (Figure 3 a), while at $10 \mathrm{~ms} / \mathrm{Px}$ the course of underdrawing lines could already be seen in the $\mathrm{Zn}-\mathrm{K}$ elemental map (Figure $3 \mathrm{~b}$ ). At a dwell time of $50 \mathrm{~ms} / \mathrm{Px}$ characteristics like the fluid application of thick lines became apparent (Figure $3 \mathrm{c}$ ). With a dwell time of $100 \mathrm{~ms} / \mathrm{Px}$ thin lines with weak $\mathrm{Zn}$-signals could be detected and visualised (Figure $3 \mathrm{~d}$ ).

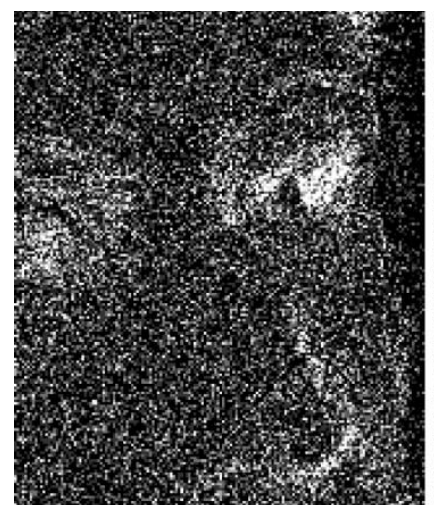

(a)

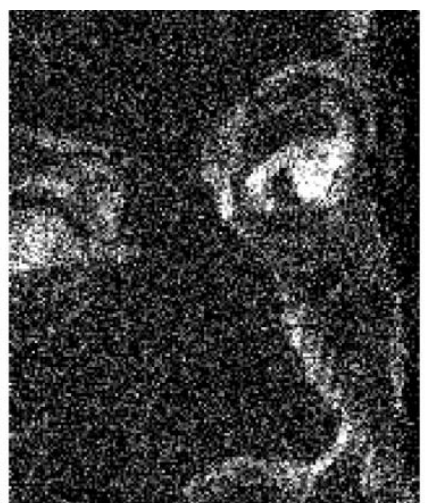

(b)

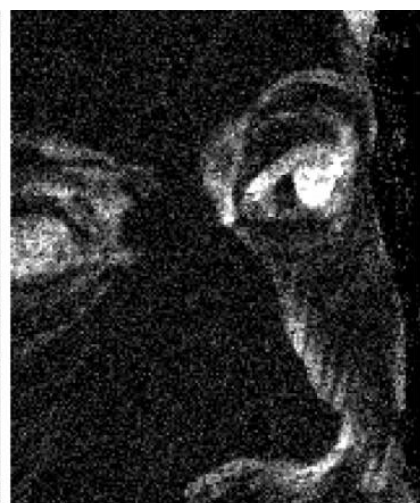

(c)

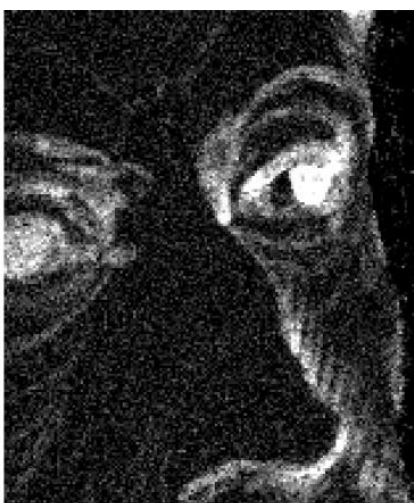

(d)

Figure 3 H. Holbein the Elder “Tree of Jesse” (Inv. № HM 6), detail of Jesse. MA-XRF Zn-K element map with differing dwell times. (a) 3,04 ms/Px; (b) $10 \mathrm{~ms} / \mathrm{Px}$; (c) $50 \mathrm{~ms} / \mathrm{Px}$; (d) $100 \mathrm{~ms} / \mathrm{Px}$.

LEDE-IRR yielded heterogenous results. A varying mix of underdrawing lines could be distinguished in the head of Jesse. Only a few $\mathrm{Zn}$-rich compositional lines were clearly visible at $1060 \mathrm{~nm}$ and transparent at $1300 \mathrm{~nm}$. Most of the underdrawing could still be reported at $1550 \mathrm{~nm}$ with differing degrees of transparency. Furthermore, $\mathrm{Zn}$-free lines became visible in IRR, which remained dark black equally to the irradiated IR wavelength. Apparently, Holbein used different ink materials for his composition simultaneously.

A second detail study of the underdrawing was carried out on King David's harp (Figure 4 a), which is depicted on the lower right side of "Tree of Jesse" (Inv. № HM 6). A detail scan with a $250 \mathrm{~ms} /$ Px dwell time proved successful in revealing parts of the underdrawing in the elemental distribution images of Fe and $\mathrm{Cu}$ (Figure $4 \mathrm{~b}-\mathrm{d}$ ). Again, the entire underdrawing with details of the application could only be visualised by $\mathrm{Zn}-\mathrm{K}$ distribution (Figure $4 \mathrm{~d}$ ). However, correlation plots of Fe and $\mathrm{Cu}, \mathrm{Mn}$ or $\mathrm{Zn}$ revealed the co-occurrence of all four elements (Figure $4 \mathrm{e}-\mathrm{g}$ ). The comparison of elemental maps and correlation plots with the VIS image shows, that Fe-, $\mathrm{Cu}-, \mathrm{Mn}$ - and $\mathrm{Zn}$-rich lines also seems to 
have been used for the final depiction of the harp's structure and material, e. g. by indicating knotholes or the levers at the lower end of the strings (Figure $4 \mathrm{~d}$, red arrows). ${ }^{5}$ Wavelength-specific IRR also showed striking results. Although varying, most of the Zn-rich lines - no matter if visible in VIS or completely covered by painting layers - grew transparent to a significant degree between $1060 \mathrm{~nm} / 1300 \mathrm{~nm}$ and $1550 \mathrm{~nm}$ (Figure $4 \mathrm{~h}$-i). ${ }^{6}$ Elemental signals could be assigned to translucent brown lines without pigment particles located either below a very thin light painting layer or upon the painting layer. While the lines localised between priming and paint layers can be assigned to the underdrawing, the brown translucent lines integrated into the depiction appear to be only partly present in the harp. Both types show a remarkable fine pattern of broad drying cracks.

\footnotetext{
${ }^{5}$ As these lines are part of the final depiction, questions arose whether the elemental signals derive from an iron gall ink or from mixing a copper-based pigment, that contains an impurity of $\mathrm{Zn}$, with an ochre pigment. In-depth evaluation of MA-XRF datasets could not clarify gained results and would require further analysis.

${ }^{6}$ The IR absorption properties in this case could be a source of error, because azurite and malachite, both Cu-based pigments, become likewise transparent between $1000 \mathrm{~nm}$ and $1300 \mathrm{~nm}$ [22] (p. 51), so that gained results could hint at different materials.
} 


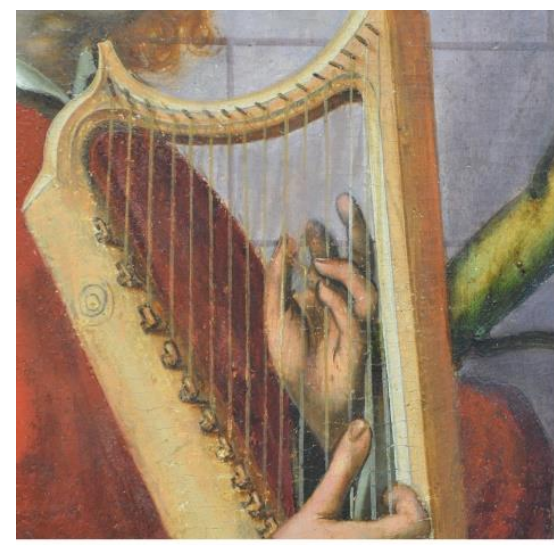

(a)

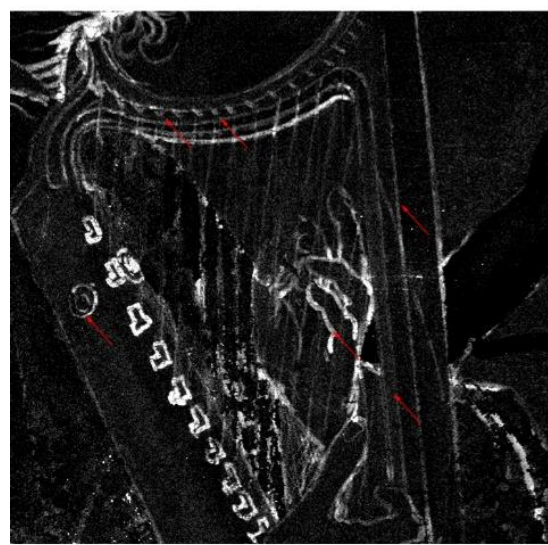

(d)

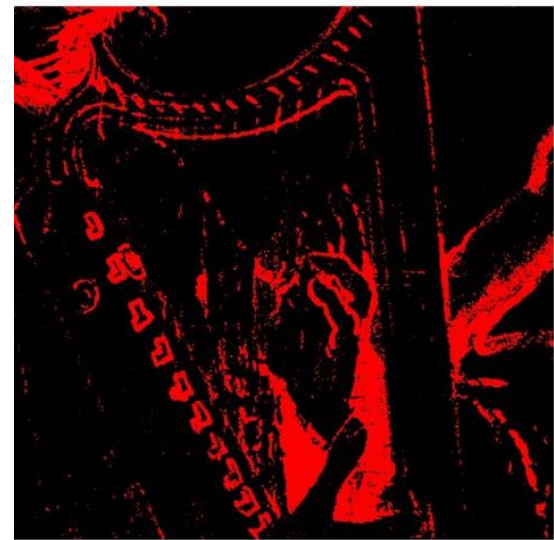

(g)

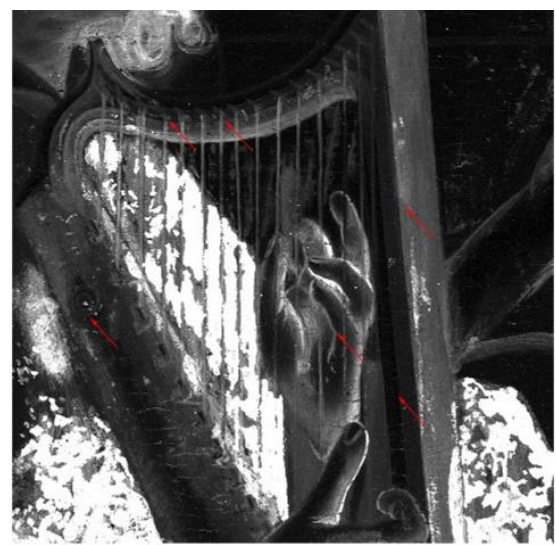

(b)

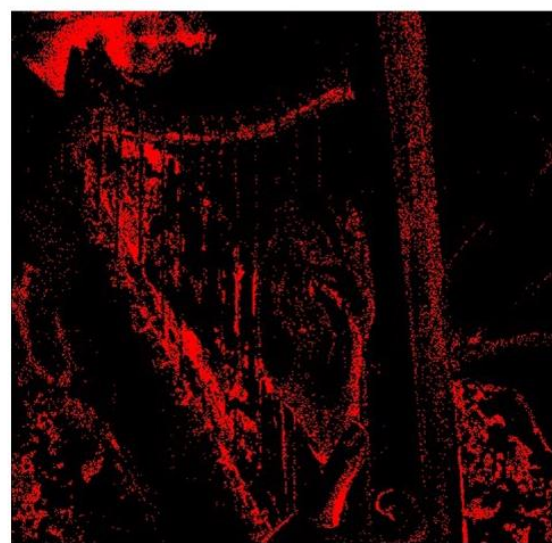

(e)

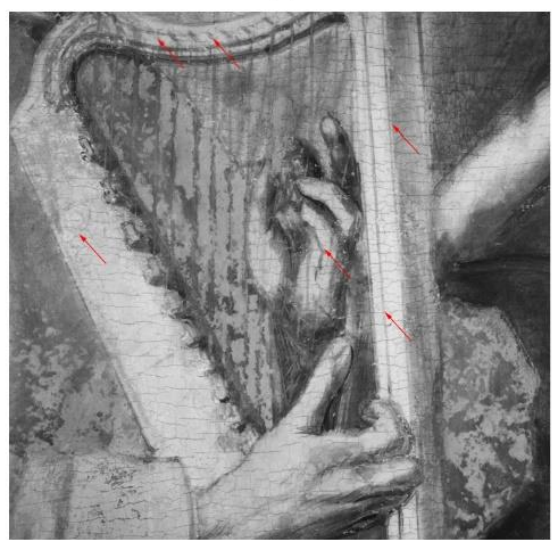

(h)

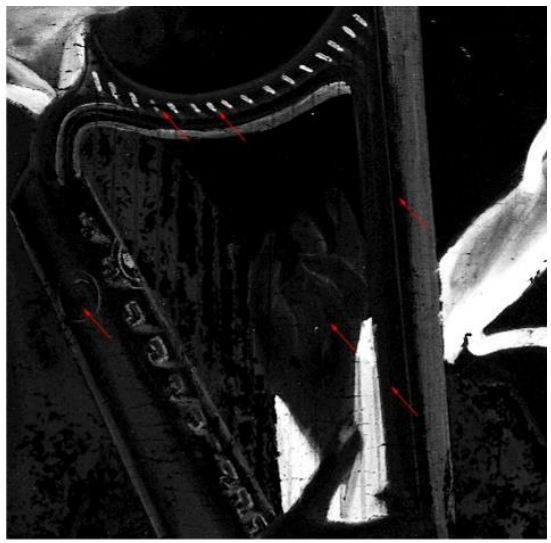

(c)

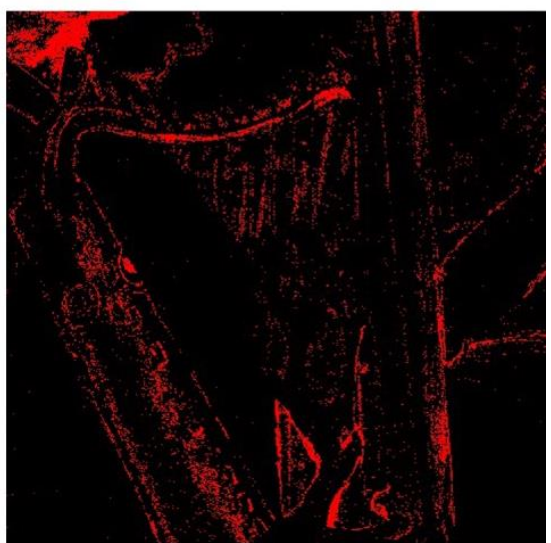

(f)

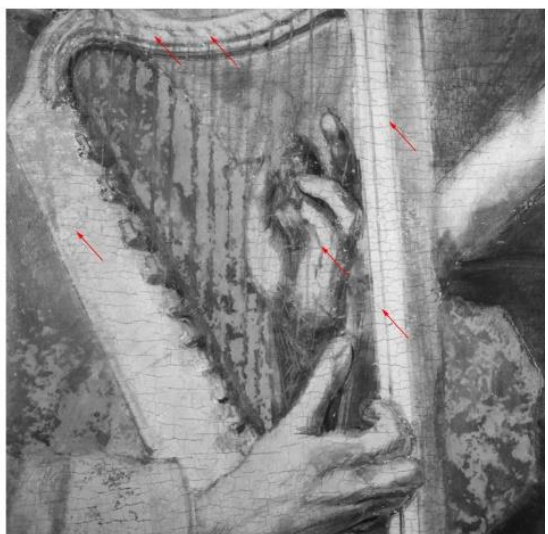

(i)

Figure 4 H. Holbein the Elder "Tree of Jesse" (Inv. № HM 6). (a) Detail of King David's harp in visual light (b) MA-XRF Fe-K element map; (c) MA-XRF CU-K element map; (d) MA-XRF Zn-K element map; (e) Correlation plot of Fe-K and Mn-K; (f) Correlation plot of Fe-K and Cu-K; (g) Correlation plot of Fe-K and Zn-K; (h) LEDE-IRR at 1060 nm; (i) LEDE-IRR at 1550 nm.

\subsubsection{Discussion}

By means of MA-XRF the iron gall ink underdrawing of the two examined panel paintings by Holbein the Elder (Inv. № HM 6 and Inv. № HM 15) became visible in all overview and detail scans by the of Zn-K distribution. In contrast to the $\mathrm{Zn}-\mathrm{K}$ elemental images, the lines of the underdrawing were only poorly visible or even completely invisible in the elemental maps of $\mathrm{Fe}, \mathrm{Cu}$ or $\mathrm{Mn}$, although an increased number of counts per second (cps) could be detected in the XRF spectra of underdrawn areas. The connection of all four elements could only be visualised by correlating elemental signals (Figure $4 \mathrm{e}-\mathrm{g}$ ). Iron gall ink lines became only partly visible within the Fe and Cu elemental maps of a detail scan 
of King David's harp, either due to the long dwell time of the scan or because some of the lines are only partly and thinly covered by painting layers. While the identification of $\mathrm{Fe}, \mathrm{Cu}$ and $\mathrm{Zn}$ is consistent with previous SEM/EDX results, MA-XRF was also able to detect Mn. This further supports Dietz hypothesis, that a vitriolum goslarensis could be assumed for the production of the ink [4] (p. 138), as vitriols from this mining site contain approximately $9 \% \mathrm{MnSO}_{4}$ [6] (p. 130). However, although the Rammelsberg in Goslar was apparently the largest production site for vitriol in Germany in the $16^{\text {th }}$ century (e. g. in 1577, 250 tons were produced), from German pharmacy price lists (taxae) we know of other German mining sites of which we do not know the chemical composition of the vitriol [7].

As there are no $\mathrm{Zn}$-based historical pigments before the $19^{\text {th }}$ century, using $\mathrm{Zn}-\mathrm{K}$ elemental maps for visualising iron gall inks firstly seems unsusceptible to error. Yet, vitriols - with or without $\mathrm{Zn}$ - were also used as additives to alter the properties of paints [32] (p. 42). Moreover, $\mathrm{Zn}$ is a common impurity in copper-based pigments [12] (p. 18), as is also apparent in the MA-XRF overall scans of "Tree of Jesse" (Inv. № HM 6) (Figure 2 b, 2 d). Therefore, the presence of a Cu-based pigment cannot be completely excluded if only MA-XRF results are considered. Due to overlapping reflectance properties of iron gall ink and Cu-based pigments like azurite or malachite, both materials cannot be clearly distinguished from each other by wavelength-specific IRR. Moreover, in this case LEDE-IRR results varied strongly because the visibility of underdrawing lines is influenced by various parameters such as layer thickness and the admixtures of carbon-based black pigments. Nonetheless, the different reflectance properties of the underdrawing lines are not only consistent with the differing visibility of compositional lines in MA-XRF distribution images, but also the general material diversity of the Frankfurt altarpiece determined by Dietz [4] (p. 505-514). The dark black lines visible in IRR and invisible in the Zn-K distribution images could indicate, that next to iron gall ink pure carbon-based black pigments were used for underdrawing the "Tree of Jesse" (Inv. № HM 6). The complexity of the results presented as well as variations of quality and style described earlier by Dietz [4] (p. 3) hint at a multi-stage composition process, that was partly executed directly on the panel. Dietz was furthermore able to prove that Holbein the Elder deliberately used underdrawing lines as part of his final depiction [4] (p. 3). It is therefore likely to deduce from the results of the MA-XRF detail scan of King David's harp, that iron gall ink could have been utilised within the painting process to partly characterise the wooden material and structure of the harp.

\subsection{Giovanni Battista Cima da Conegliano "Virgin and Child" (Inv. № 852)}

Giovanni Battista Cima da Conegliano (c. 1459-c. 1517) was an Italian Renaissance painter who worked in Venice for most of his life. The panel painting "Virgin and Child" (1500-1501), belonging to the collection of the Städel Museum, shows a typical motif of the artist (Figure 5 a). It was probably initially conceived for a full-figure altarpiece, but was later transformed into a half-figure format [33] (p. 136-137). Conventional IRR with a Vidicon (Figure 5 b) revealed only few underdrawing lines [33] (p. 131). 


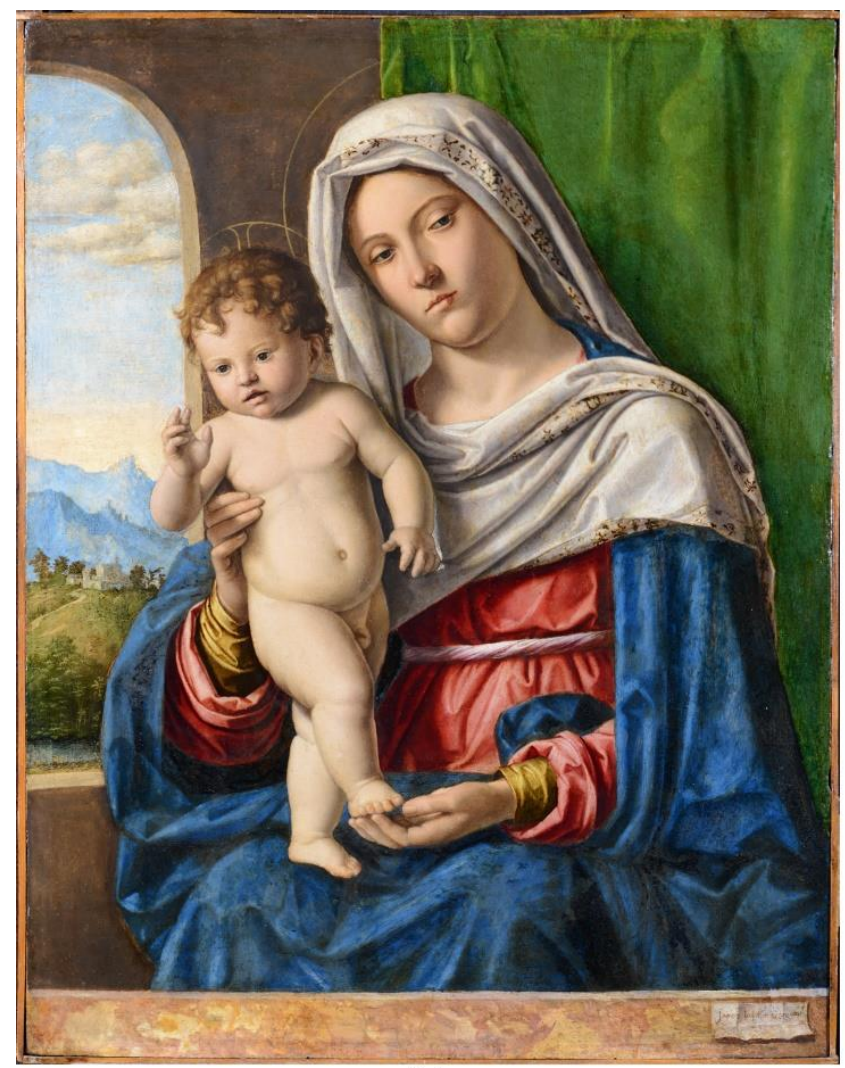

(a)

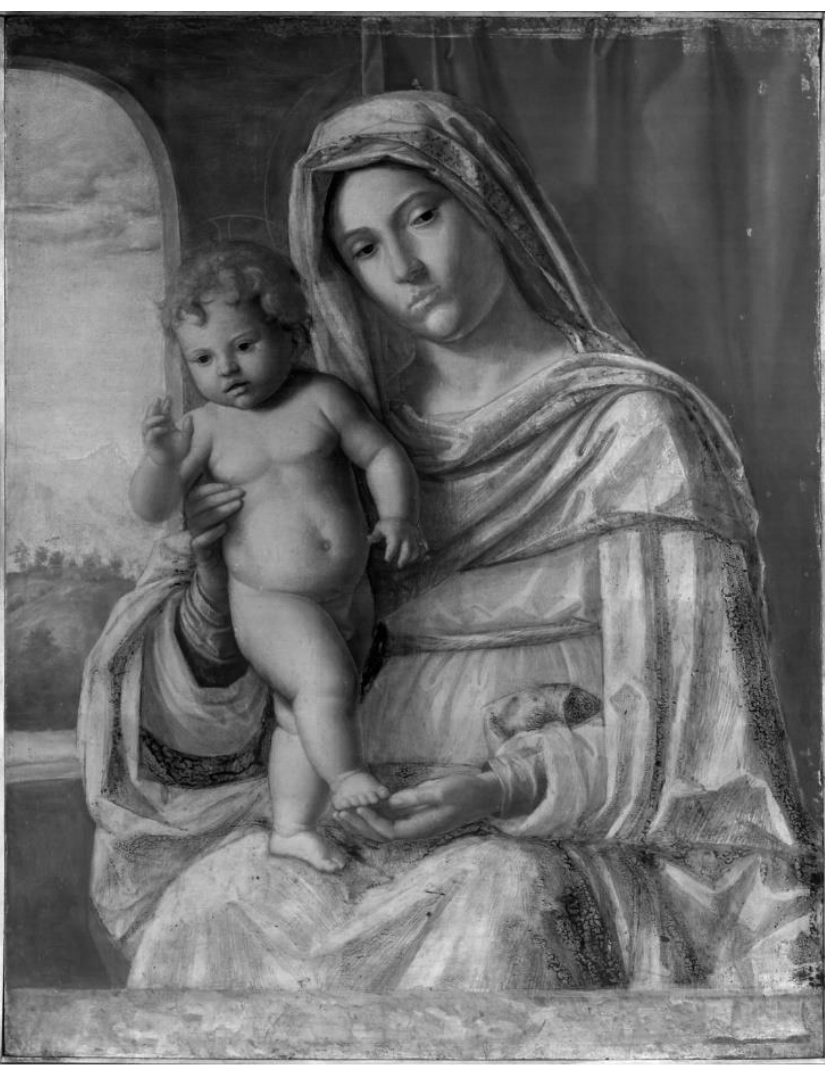

(b)

\footnotetext{
${ }^{7}$ Identified by SEM/EDX during this study.
} 


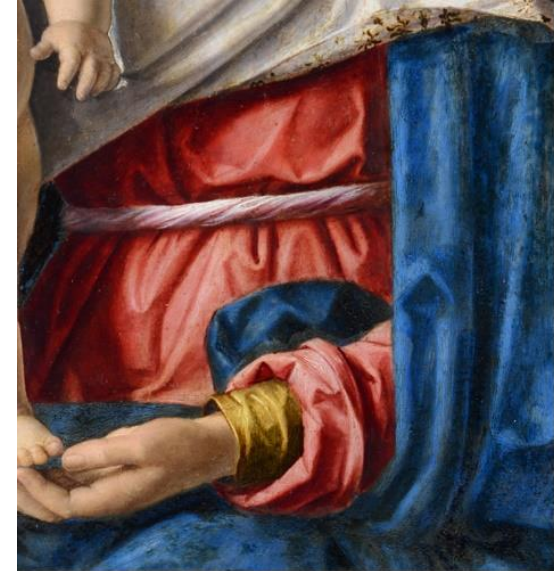

(a)

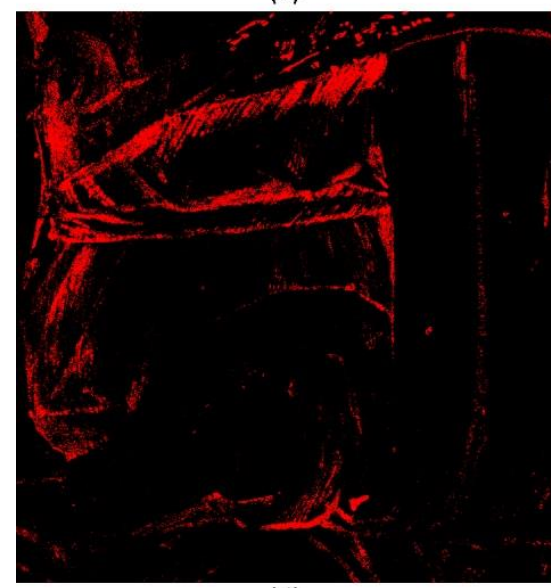

(d)

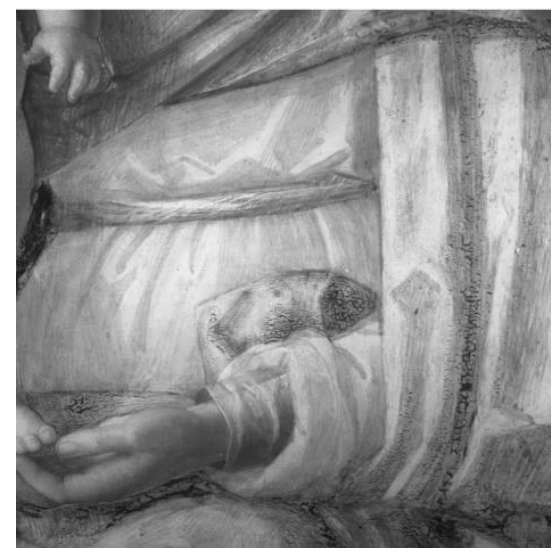

(g)

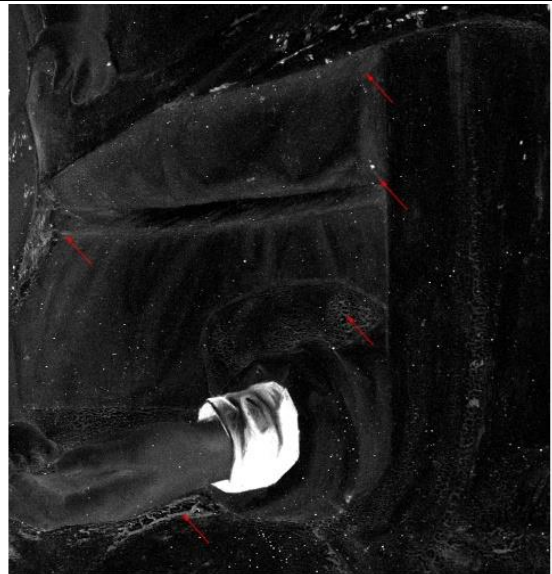

(b)

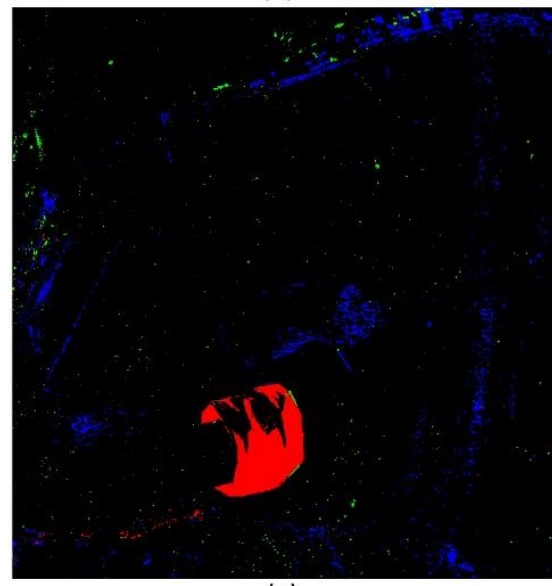

(e)

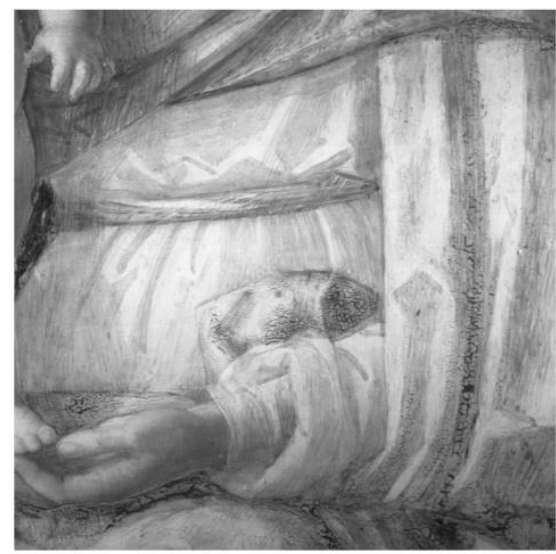

(h)

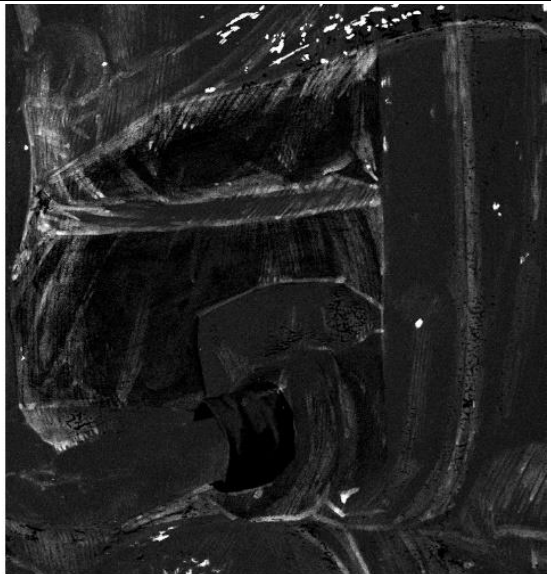

(c)

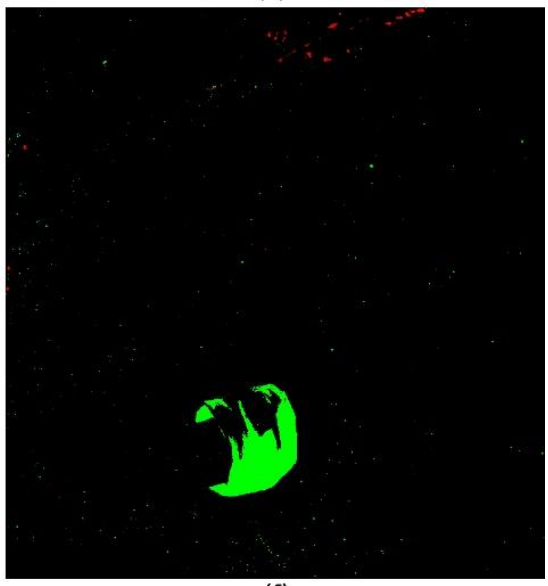

(f)

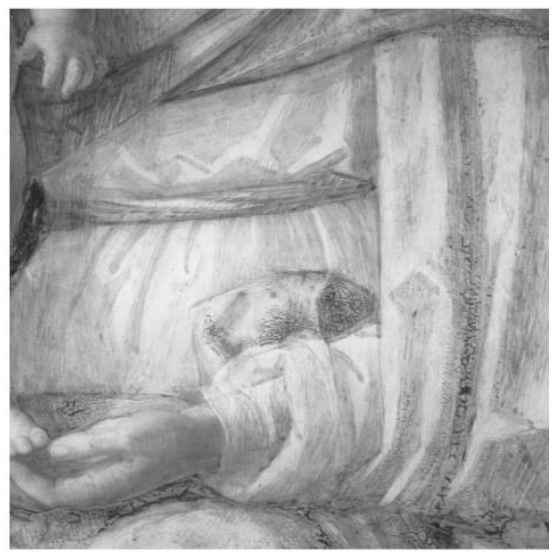

(i)

Figure 6 G. B. Cima da Conegliano "Virgin and Child" (Inv. № 852). (a) Detail of the Madonna's dress; (b) MA-XRF Fe-K element map; (c) MA-XRF Zn-K element map; (d) Correlation plot of Fe-K and Zn-K; (e) Correlation plot of Fe-K and Cu-K; (f) Correlation plot of Fe-K and Mn-K; (g) LEDE-IRR at $1060 \mathrm{~nm}$; (h) LEDE-IRR at $1300 \mathrm{~nm}$; (i) LEDE-IRR at $1550 \mathrm{~nm}$.

By stereomicroscopy two different types of underdrawing could be distinguished from each other (Figure $7 \mathrm{a}-\mathrm{b}$ ). Visual features of type 1 show translucent lines whose colour vary from light- to dark-brown depending on the thickness of the layer (Figure 7 a). In thickly applied areas, a unique ageing pattern characterised by fine drying cracks becomes visible. In addition, paint layers covering dark brown lines appear to be damaged, too. Particularly blue areas, such as the Virgin's dress, are shaped by thick drying cracks with a diameter up to up to $1 \mathrm{~mm}$, in which the underlying brown underdrawing layer is revealed. In contrast, white or red painting layers are more stable and only show a pattern of 
very fine losses $(<1 \mathrm{~mm})$, in which the underdrawing is either revealed or partly lost. ${ }^{8}$ The aforementioned ageing pattern of the brown-black underdrawing becomes further apparent in dark field illumination of a cross-section sample taking from a thickly applied composing line, as the dark translucent layer is divided by drying cracks every 20 to $50 \mu \mathrm{m}$ (Figure $7 \mathrm{c}$ ). When exposing micro-samples to UV radiation (Figure $7 \mathrm{~d}$ ) the underdrawing appears black. By means of SEM/EDX analysis, Fe, $\mathrm{Zn}$ and Al could be identified within the underdrawing layer, indicating the usage of iron gall ink. The ink was probably mixed with an organic component.

By stereomicroscopy, type 2 could solely be localised below the light violet cord of the Virgin's dress (Figure $7 \mathrm{~b}$ ). While 283 appearing to be of green colour under the stereomicroscope, cross-section reveals a particle-rich thin black layer (Figure $7 \mathrm{e}-\mathrm{f}) .{ }^{9}$ In contrast to the brownish underdrawing lines, this type of underdrawing remains slightly darker when excited with $1500 \mathrm{~nm}$. By SEM/EDX, carbon-black particles could be determined, which are embedded in an Fe-, Znan Al-rich matrix.

\footnotetext{
${ }^{8}$ In this study, typical damage symptoms of the ink and covering layers are limited to areas, where the underdrawing has been applied thickly or overlying paint layers contain blue pigments. Hence, this ageing pattern does not necessarily appear when an iron gall ink has been used, as e. g. Frankfurt Dominican Altarpiece, and might be dependant on the recipe used for the production of the ink [4] (p. 134), or other reasons.

${ }^{9}$ The thin layer pobably only appears to be green due to the surrounding red paint layers.
} 


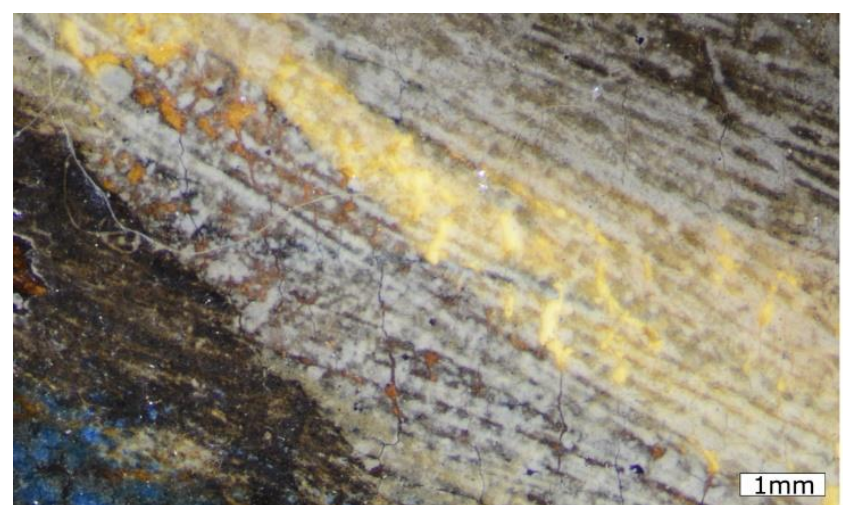

(a)

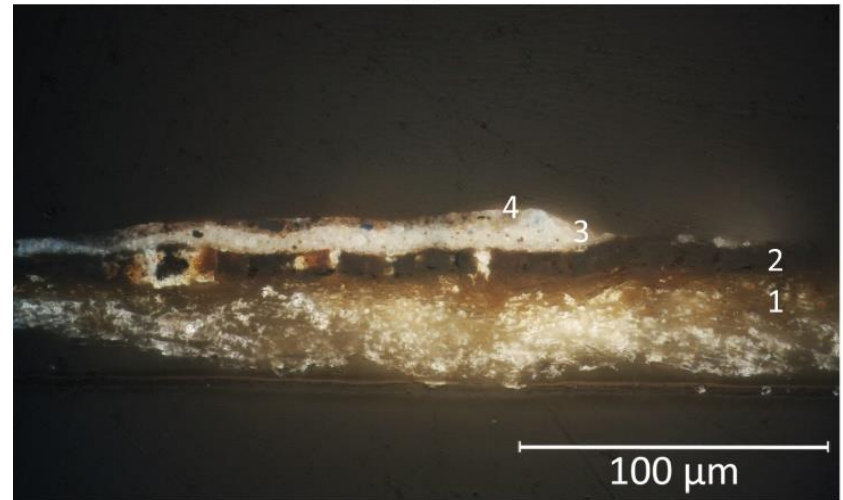

(c)

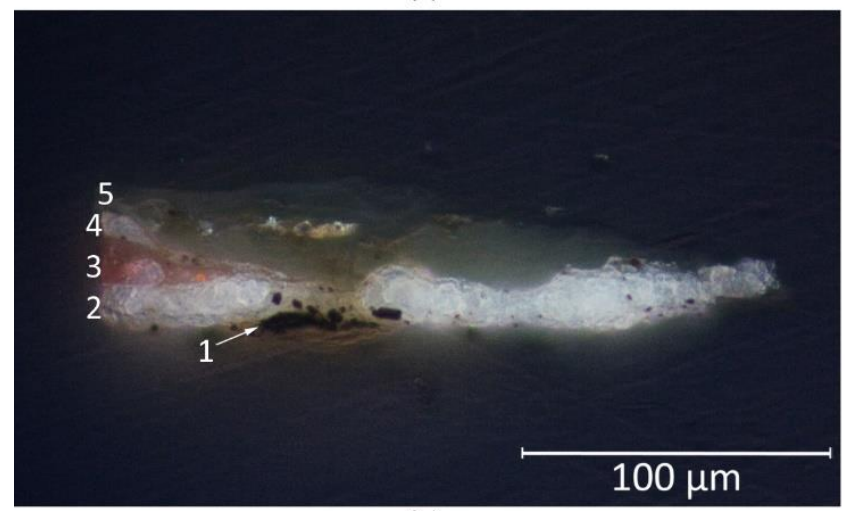

(e)

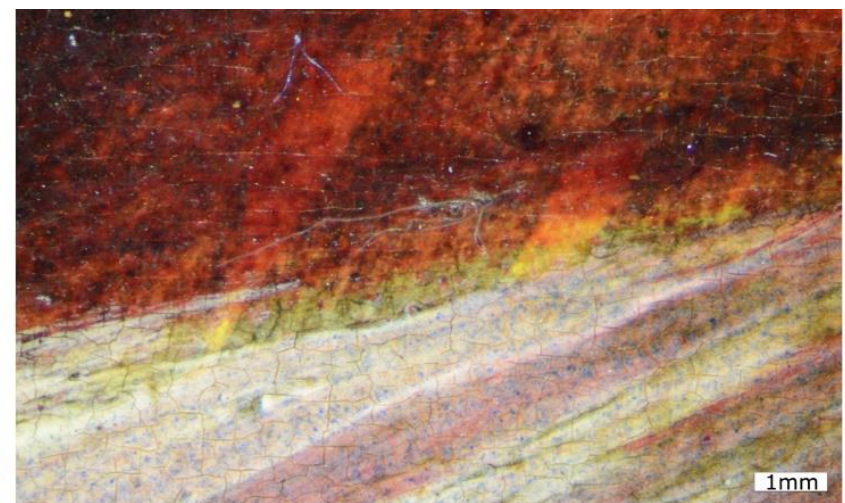

(b)

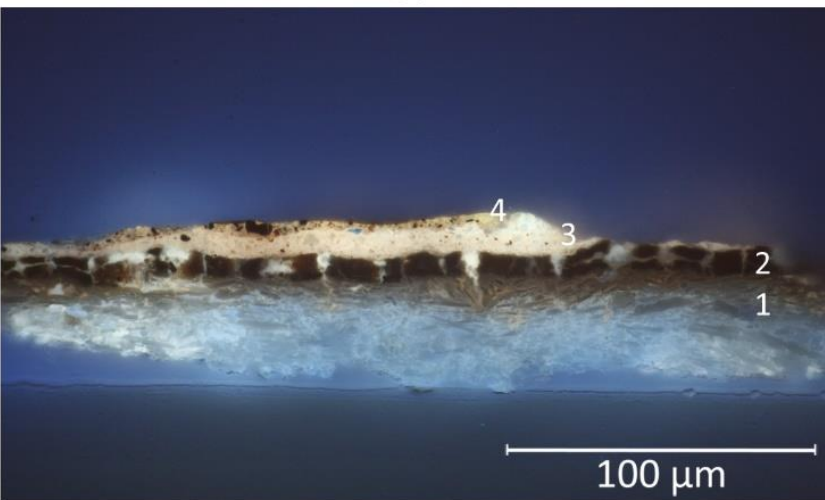

(d)

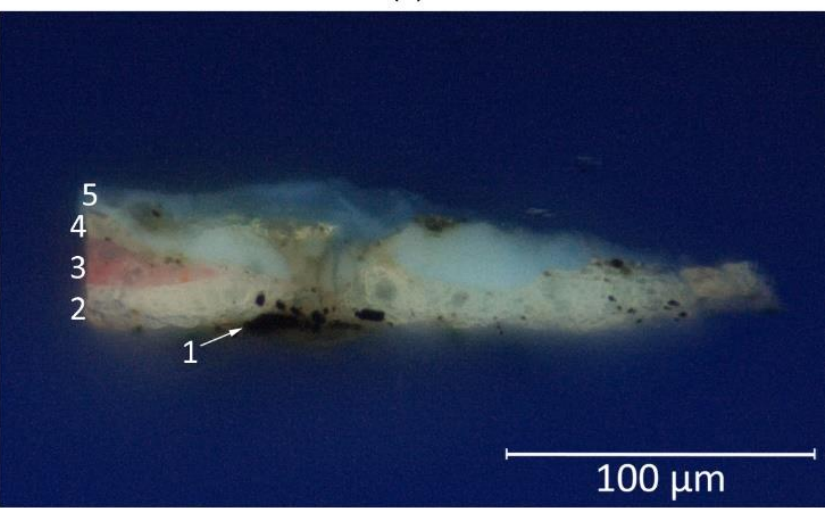

(f)

Figure 7 G. B. Cima da Conegliano "Virgin and Child" (Inv. № 852). (a) Microscopic image of the brown translucent underdrawing; (b) Microscopic image of the second type of underdrawing underneath the cord of the Virgin's dress; (c) Cross-section S1 in dark field of the brown translucent underdrawing; (d) Cross-section S1 in UV; (e) Cross-section S2 in dark field of the second type of underdrawing; (f) Cross-section S2 in UV.

\subsubsection{Discussion}

All characteristics identified by MA-XRF, stereomicroscopy, cross-section in dark field and UV as well as SEM/EDX are typical for iron gall inks. The only feature that does not hint at an iron gall ink is the visibility of the underdrawing at $1550 \mathrm{~nm}$, which is either due to the partly thick application of the lines of type 1 (Figure $7 \mathrm{a}, \mathrm{c}-\mathrm{d}$ ) or on the admixture of carbon-black pigments in type 2 underdrawing (Figure $7 \mathrm{~b}, \mathrm{e}-\mathrm{f}$ ).

Published art-technological results of other paintings by Giovanni Battista Cima da Conegliano describe a comparable use of different materials. In the underdrawing of the unfinished painting "Virgin and Child with S. Andrew and S. Peter" at the National Gallery Scotland (Inv. № 1190), a small amount of carbon-black pigment particles could be 
identified within the iron gall ink underdrawing. This could either indicate the mixture of both materials or, as Dunkerton and Roy concluded, a preliminary drawing executed with charcoal that was afterwards redrawn with an iron gall ink, as recommended in Cennino Cennini's famous tract “Il Libro dell'Arte" written around 1390 [26] (p. 8) [34] (p. 18). Moreover, uncovered underdrawing lines of this unfinished painting show characteristics both of a quill and a brush, which is well in accordance with quill traces identified within the $\mathrm{Zn}$ elemental distribution map of the Städel's painting. Iron gall ink could also be determined in the underdrawing of Cima da Conegliano's "Incredulity of St. Thomas", painted between 1502-1504, at the National Gallery London (Inv. № NG 816) [1] (p. 31). Carbon-based black pigment underdrawings have been further detected in other panel paintings, such as the "Pala" from 1492, part of the high altarpiece of the cathedral of Conegliano, by cross-section analysis [35] (p.36).

By means of MA-XRF and SEM/EDX a high amount of $\mathrm{Zn}$ could be identified within the underdrawing. It can be hence concluded, that a vitriol from a Zn-rich extraction site was used for the production of the ink.

Formerly believed to be underdrawn with only a few lines and an unspecified liquid material, the recent examination of Cima da Conegliano's "Virgin and Child" (Inv. № 852) was not only able to visualise the complex and detailed composition, but even more, to enclose the materiality of the underdrawing by determining the inorganic components by MA-XRF (Fe and $\mathrm{Zn}$ ). In this case, IR reflectance properties studied by LEDE-IRR were not very significant, which could be ascribed to different reasons, such as an admixture of carbon-black pigments or the thick application of the ink underdrawing. Visual properties observed by stereomicroscopy - especially the ink's colour, translucency and typical ageing pattern - were more informative and led to the conclusion, that an iron gall ink was used. This was confirmed by SEM/EDX analysis that detected further organic components, which cannot be deduced by the applied approach.

\section{Conclusions}

For the very first time, two iron gall ink underdrawings could be deliberately visualised and studied in their overall application, characteristics and style by using non-invasive analysis. Although material identification solely based on non-destructive spectroscopic methods such as IRR and XRF is controversial, the combination of different analytical techniques allowed to enclose the materiality of the underdrawing.

In all cases, $\mathrm{Zn}$ signals deriving from a vitriol with a high amount of $\mathrm{ZnSO}_{4}$ were essential for MA-XRF mapping, not only to visualise underdrawing lines, but also for material characterisation. The potential invisibility of an iron gall ink underdrawing in the $\mathrm{Fe}, \mathrm{Cu}$ and $\mathrm{Mn}$ distribution could be a major issue if a $\mathrm{Zn}$-free vitriol was used for the ink's production. As shown in the case of the "Tree of Jesse" by Holbein the Elder (Inv. № HM 6), this problem could be partly solved by using correlation plots (Figure $4 \mathrm{e}-\mathrm{g}$ ). Further, the identification of two differing $\mathrm{Zn}$-containing underdrawings in Cima da Conegliano's painting shows that material identification cannot be solely based on one nondestructive analytical technique. Therefore, this paper presented an advanced use of IRR using specific IR wavelengths for illumination. This method was able to distinguish between different types of underdrawing in the first case, whereas results were not significant in the second study presented. As IR reflectance properties are dependent on different factors, gained results are not unequivocal. Since the use of a vitriol or verdigris as drying agents are further likely for $16^{\text {th }}$ century paintings, e. g. for coloured inks used by Hans Holbein the Elder [4] (p. 137), results have to be interpreted cautiously. In both cases, additional stereomicroscopy proved essential for allocating signals and studying visual properties of the material. Complementary SEM/EDX analysis was helpful to verify results obtained by the non- 
destructive approach. In general, the outcomes of this study prove, that only by combining different analytical and post-processing methods with microscopical observations, a final conclusion on the materiality can be drawn (Table $3)$.

By visualising iron gall ink underdrawings, a new access for further studies with wider application possibilities is created - overhauling a system, in which the materiality of an underdrawing media could only be examined in case studies, which required the punctual removal of micro-samples and their examination by analytical techniques, that are only limitedly accessible. The presented analysis approach enables not only a new way of studying the whole underdrawing and not merely a selected point that might not be representative for the entire object, but also promotes interdisciplinary exchange as the gained results are readily accessible to disciplines without deep knowledge in natural sciences, as e. g. art-historians. Moreover, results can be more easily used for art education of the general public.

Table 3. Overview about gained results.

\section{Object}

$$
\text { Microscopy }
$$

MA-XRF

LEDE-IRR

SEM/EDX

Holbein the Elder

"Tree of Jesse"

(Inv. № HM 6)
Various lines, either transparent between 1060-1300 or clearly visible up to $1550 \mathrm{~nm}$
Fe, Cu, Zn, Al

$\mathrm{Fe}, \mathrm{Cu}, \mathrm{Zn}$

\section{Holbein the Elder \\ "Bearing of the Cross"}

(Inv. № HM 15)
Brown-black, transparent, no particles visible
Fe, Cu, Zn
Visible up to $1500 \mathrm{~nm}$

$$
\text { with a slightly } \quad \mathrm{Fe}, \mathrm{Cu}, \mathrm{Zn}, \mathrm{Al}
$$

\begin{tabular}{llccc}
\hline Cima da Conegliano & $\begin{array}{l}\text { Type } \\
\text { transparent, no particles visible }\end{array}$ & Fe, $\mathrm{Zn}$ & $\begin{array}{c}\text { Visible up to } 1500 \mathrm{~nm} \\
\text { with a slightly }\end{array}$ \\
"Virgin and Child" & & & Fe, $\mathrm{Zn}, \mathrm{Al}$ \\
enhanced transparency
\end{tabular}

(Inv. № 852)

Type 2: green(?)/ black, thinly $\quad F e, Z n \quad$ Visible up to $1500 \mathrm{~nm} \quad$ Fe, Zn, Al
$\begin{aligned} & \text { applied with visible particles }\end{aligned}$

\section{Outlook}

Iron gall ink is commonly thought to have been used only rarely for underdrawing paintings. Considering that this is solely assumed because non-carbon-based underdrawings poorly register in conventional IRR and invasive analysis is only applied in single in-depth studies on individual paintings, the results presented in this article could hint at a much broader use in Italy and Germany around 1500. A broad application of this novel non-invasive analytical approach could therefore expand knowledge on non-carbon-based underdrawings and overturn current beliefs. However, a more detailed evaluation of the possibilities and limits of the analysis of different iron gall inks requires further research on test specimens, which is currently being conducted at the Städel Museum Frankfurt. Further unidentified components in the underdrawing of Cima da Conegliano's "Virgin and Child" (Inv. № 852) will be analysed by additional analysis such as FTIR/FPA imaging, which is going to be conducted on micro-samples in the next months. A few of the depicted portraits of the Dominican Altarpiece are based on portrait studies, that were beforehand drawn on paper by Holbein the Elder, e. g. a Dominican monk [36] (p. 222). Technology and style of the portraits' underdrawings will be compared to new results on the materiality and execution of the portrait studies on paper [37] (p. 56). 


\section{Declarations}

Availability of data and materials: The datasets generated and analysed during the current study are not publicly available as they are being further evaluated for the doctoral thesis of the corresponding author but are available from the corresponding author on reasonable request.

Competing interests: The authors declare that they have no competing interests.

Funding: This research was funded by Dr. Rolf M. Schwiete Stiftung, Mannheim, Germany and the Städel Museum Frankfurt. The funders had no role in the design of the study, in the collection, analysis or interpretation of data, in the writing of the manuscript or in the decision to publish the results.

Authors' contributions: MG wrote the manuscript which was revised by JS and CK. MA-XRF scanning and data evaluation and LEDE-IRR of all paintings as well as cross section and SEM/EDX analysis of Inv. № 852, MG; cross-section and SEM/EDX results of the paintings by Holbein the Elder were kindly provided by Stephanie Dietz. All authors have read and agreed to the published version of the manuscript.

Acknowledgments: This research is part of a doctoral thesis by Mareike Gerken at the Institute for Conservation Sciences at the State Academy of Art and Design Stuttgart on the visualisation and identification of different noncarbon-based underdrawings such as ochre pigments, iron gall inks and metal points. The doctoral thesis is part of an interdisciplinary research project on MA-XRF Research on European Paintings from the Städel Museum and on Paleontological Findings from the Senckenberg Research Institute and Natural History Museum. The project is a cooperation between the Städel Museum Frankfurt, the Art-historical Institute at the Goethe University Frankfurt, the Institute of Materials Science at the Technical University of Darmstadt and the Senckenberg Research Institute and Natural History Museum Frankfurt. The authors would like to thank Stephan Knobloch (Head of Painting Conservation, Städel Museum Frankfurt) and, furthermore, Dr. Stephanie Dietz (Scientist at the Laboratory for Archaeometry and Conservation Sciences in the Department of Conservation, State Academy of Art and Design Stuttgart) for providing cross-section and SEM/EDX results of the Dominican Altarpiece by Holbein the Elder.

\section{References}

1. Kirby J, Roy A, Spring M. The Materials of Underdrawing. In: Bomford D, editor. Underdrawings in Renaissance Paintings. London: National Gallery Company Ltd.; 2002. p. 26-37.

2. Krekel C. Chemische Struktur historischer Eisengallustinten. In: Banik G, Weber H, editors. Tintenfraßschäden und Ihre Behandlung. Stuttgart: W. Kohlhammer; 1999, p. 25-36. For an English version see: Krekel C. The Chemistry of Historical Iron Gall Inks. International Journal of Forensic Document Examiners. 1999;5:54-58.

3. White R, Pilc J, Kirby J. Analyses of Paint Media. National Gallery Technical Bulletin. 1998;19:74-95.

4. Dietz S. Malen mit Glas - Studien zur Maltechnik von Hans Holbein d. Ä. In: Kölner Schriften zur Geistes- und Gesellschaftswissenschaftlichen Forschung. 2016. https://cos.bibl.thkoeln.de/frontdoor/index/index/docld /324. Accessed 12 March 122021.

5. Valadas S, Freire R, Cardoso A, Mirão J, Vandenabeele P, Caetano JO, Candeias A. New insight on the underdrawing of 16th Flemish-Portuguese easel paintings by combined surface analysis and microanalytical techniques. Micron 2016;85; doi:10.1016/j.micron.2016.03.004. 
6. Hickel E. Chemikalien im Arzneischatz deutscher Apotheken des 16. Jahrhunderts, unter besonderer Berücksichtigung der Metalle. 1st ed. Stuttgart: Deutscher Apotheker Verlag; 1963.

7. Krekel C, Burmester A, Haller U. Kurzmitteilungen aus dem Münchner Taxenprojekt: Vitriol. RESTAURO 2005;8:562-565.

8. Alfeld M, de Viguerie L. Recent developments in spectroscopic imaging techniques for historical paintings - A review. Spectrochimica Acta Part B. 2017;136:81-105; doi:10.1016/j.sab.2017.08.003.

9. Dik J, Janssens K, van der Snickt G, van der Loeff L, Rickers K, Cotte M. Visualization of a Lost Painting by Vincent van Gogh Using Synchrotron Radiation Based X-ray Fluorescence Elemental Mapping. Anal Chem. 2008;80:6436-6442; doi:10.1021/ac800965g.

10. Alfeld M, Vaz Pedroso J, van Eikema Hommes M, van der Snickt G, Tauber G, Blaas J, et al. A mobile instrument for in situ scanning macro-XRF investigation of historical paintings. J Anal At Spectrom. 2013;28:760-767; doi:10.1039/c3ja30341a.

11. Legrand S, Vanmeert F, van der Snickt G, Alfeld M, de Nolf W, Dik J, et al. Examination of historical paintings by state-of-the-art hyperspectral imaging methods: from scanning infra-red spectroscopy to computed X-ray laminography. Herit Sci. 2014;2:13; doi: 10.1186/2050-7445-2-13.

12. Wolf F, Weber C, Seeberg S, Sander J, Hoffmann P, Flege S, et al. Die bildgebende RöntgenfluoreszenzUntersuchung des Altenberger Altars von ca. 1330: Neue Befunde zur rückseitigen Bemalung eines der frühesten Hochaltarretabel im deutschsprachigen Raum. Zeitschrift für Kunsttechnologie und Konservierung 2017;31:5-33.

13. van Grieken RE, Markowicz AA. Handbook of X-Ray Spectrometry. 2nd ed. New York: Marcel Dekker; 2002.

14. Hartwieg B. Spurensuche, Technologische Beobachtungen, Untersuchungen und Schlussfolgerungen zu den Berliner Tafeln Cenninis. In: Löhr WD, Weppelmann S, editors. Fantasie und Handwerk: Cennino Cennini und die Tradition der toskanischen Malerei von Giotto bis Lorenzo Monaco. München: Hirmer Verlag; 2008. p. 81102.

15. Hahn O, Gorny HE. Zerstörungsfreie Charakterisierung historischer Eisengallustinten mittels Röntgenfluoreszenzanalyse. Zeitschrift für Kunsttechnologie und Konservierung 2000;14:384-390.

16. Hahn O, Malzer W, Kanngiesser B, Beckhoff B. Characterization of iron-gall inks in historical manuscripts and music compositions using $x$-ray fluorescence spectrometry. X-Ray Spectrom. 2004;33:234-239; doi:10.1002/xrs.677.

17. Hahn O, Kanngiesser B, Malzer W. X-ray Fluorescence Analysis of Iron Gall Inks, Pencils and Coloured Crayons. Stud Conserv. 2005;50:23-32; doi:10.1179/sic.2005.50.1.23.

18. Bergmann U. Archimedes brought to light. Phys World 2007;20:39-42; doi:10.1088/2058-7058/20/11/39.

19. Glaser L, Shevchuk I, Tolkiehn M, Rabin I, Hahn O. Improving Iron Gall Ink Palimpsest X-ray Fluorescence Element Mapping Analysis. In: Börner W, Uhlirz S, editors. Proceedings CHNT 23. Wien: Museen der Stadt Wien - Stadtarchäologie; 2018. 
20. Turner NK, Schmidt Patterson C, MacLennan D, Trentelman K. Visualizing underdrawings in medieval manuscript illuminations with macro-X-ray fluorescence scanning. X-Ray Spectrom. 2019;48:251-261; doi:10.1002/xrs.2956

21. Yan S, Huang JJ, Daly N, Higgitt C, Dragotti PL. Revealing Hidden Drawings in Leonardo's "The Virgin of the Rocks" from Macro X-Ray Fluorescence scanning data through element line-localisation. Proceedings ICASSP 45. 2020. doi:10.1109/ICASSP40776.2020.9054460.

22. Geffken K. LEDs als Strahlungsquelle für die Infrarotreflektografie. Master Thesis, Stuttgart: State Academy of Art and Design; 10.09.2014.

23. Siejek A. Identifikation und Rekonstruktion graphischer Mittel auf dem Malgrund. In: Sandner I, editor. Die Unterzeichnung auf dem Malgrund. Graphische Mittel und Übertragungsverfahren im 15.-17. Jahrhundert. München: Siegl; 2004. p. 13-145.

24. Mrusek R, Fuchs R, Oltrogge D. Spektrale Fenster zur Vergangenheit: Ein neues Reflektographieverfahren zur Untersuchung von Buchmalerei und historischem Schriftgut. Naturwissenschaften 1995;82:68-79.

25. Tepest, R. Der Einsatz von Filtern in der IR-Reflektographie. In: Sandner I, editor. Unsichtbare Meisterzeichnungen auf dem Malgrund: Cranach und seine Zeitgenossen. Erfurt: Druck und Repro Verlag; 1998. p. 44-50.

26. Dunkerton K, Roy A. The Technique and Restoration of Cima's 'The Incredulity of S. Thomas'. National Gallery Technical Bulletin 1986;10:4-10.

27. Alfeld $M$, Janssens $K$. Strategies for processing mega-pixel X-ray fluorescence hyperspectral data: a case study on a version of Caravaggio's painting Supper at Emmaus. J Anal At Spectrom. 2005;30:777-789; doi: 10.1039/c4ja00387j.

28. Cotte M, Fabris T, Agostini G, Motta Meira D, de Viguerie L, Solé VA. Watching Kinetic Studies as Chemical Maps Using Open-Source Software. Anal Chem. 2016;88:6154-6160; doi: 10.1021/acs.analchem.5b04819.

29. Solé VA, Papillon E, Cotte $M$, Walter $P$, Susini J. A multiplatform code for the analysis of energy-dispersive $X-$ ray fluorescence spectra. Spectrochimica Acta Part B 2007;62:63-68; doi: 10.1016/j.sab.2006.12.002.

30. Dittmar G. Bedienungsanleitung für Infrarot-LED-Strahler zur Anwendung in der Infrarotreflektographie. Aalen: Steinbeis Transfer Centre, Aalen University; 2014. Unpublished report.

31. Brinkmann B, Kemperdick S. Deutsche Gemälde im Städel 1500-1550. 1st ed. Mainz: Phillip von Zabern; 2005.

32. Billinge R, Campbell L, Dunkerton J, Foister S, Kirby J, Pilc J, et al. Methods and materials of Northern European painting in the National Gallery, 1400-1550. National Gallery Technical Bulletin 1997;18:6-55.

33. Sander J. Italienische Gemälde im Städel 1300-1550: Oberitalien, Die Marken und Rom. 1st ed. Mainz: Phillip von Zabern; 2004.

34. Berger E. Quellen und Technik der Fresko-, Oel- und Temperamalerei des Mittelalters. Von der byzantinischen Zeit bis einschließlich der "Erfindung der Ölmalerei" durch die Brüder van Eyck. 2nd ed. Vaduz: Sändig Reprint Verlag; 1982. 
35. Fassina V, Frezzato F. La campagna di analisi sulle tre opera di Cima presenti nella diocese di Vittori Veneto: studio dei materiali pittorici e delle tecniche esecutive. In: Spiazzi AM, Villa GCF, editors. Cima da Conegliano. Analisi e restauri. Una giornata di studi, Milano:SilvanaEditoriale; 2010, p. 23-42.

36. Krause K. Hans Holbein der Ältere. 1st ed. München, Berlin: Deutscher Kunstverlag; 2002.

37. Dietz G. Es ist noch kein Meister von Himmel gefallen: Neue Erkenntnisse zu den Silberstiftzeichnungen Hans Holbeins des Älteren und seinem Einfluss auf die Zeichentechnik seiner Söhne. In: Kemperdick S, Roth M, editors. Holbein in Berlin. Die Madonna der Sammlung Würth mit Meisterwerken der Staatlichen Museen zu Berlin. Petersberg: Michael Imhof Verlag; 2016. p. 53-61.

Figure 1 a: CC BY-SA 4.0 Städel Museum, Frankfurt, https://creativecommons.org/licenses/by-sa/4.0/deed.de.

Figure 1 b-d: (C) Stephanie Dietz, edited by M. Gerken.

Figure 2 a-d, 3 a-d, 4 a-i, 6 a-i, 7 a-f: (c) Städel Museum, Frankfurt am Main - Department for Art-Technology and

Figure 5 a C Städel Museum, Frankfurt am Main, Foto: U. Edelmann.

Figure 5 b C Städel Museum, Frankfurt am Main.

\section{Abbreviations}

\begin{tabular}{l|l} 
IR & Infrared radiation \\
IRR & Infrared reflectography \\
LEDE-IRR & LED-excited infrared reflectography \\
MA-XRF & Micro-X-ray fluorescence scanning \\
nm & Wavelength \\
P-XRF & Point X-ray fluorescence analysis \\
SEM/EDX & Scanning electron microscopy with energydispersive X-ray micro-analysis \\
XRR & X-ray radiography
\end{tabular}




\section{Supplementary Files}

This is a list of supplementary files associated with this preprint. Click to download.

- GerkenetalSupplementaryMaterial.pdf

- Suppl1.png

- Suppl2.tif

- Suppl3.tif 